\title{
NEEDS OF A PARAPLEGIC IN DEVELOPING COUNTRIES
}

\author{
W. G. Rama Rao, M.S., F.R.C.S. \\ All-India Institute of Physical Medicine and Rehabilitation (Govt. of India), \\ Haji Ali Park, Mahalaxmi, Bombay, India 400034
}

THE spinal cord injured are the most difficult to rehabilitate, not only because of their motor disability but because there are so many neglected problems which need to be solved for the 'Paraplegic' to achieve meaningful life. Added to this are other problems unique to the spinal cord injured in developing countries.

\section{The Institute}

The art of rehabilitating the physically handicapped was introduced to India through the All-India Institute of Physical Medicine and Rehabilitation in 1955, when an ad hoc committee of the U.N., UNICEF, W.H.O. and UNESCO chose Bombay for a pilot project in the South East Asian Region. This National Institute has grown to the stage that it can now reminiscent and assess the ineffectiveness of programmes copied.

It may not be construed as impertinent, if I quote a report from the 490page Asia agricultural survey, to point out how well 'Conceived' Western technology fails to 'deliver' to the oriental needs.

'The so-called green revolution based on the creation of new high yield strains of rice and wheat, seemed about to cause a spectacular leap forward in agricultural production and with western-trained experts appeared ready to tackle the problems of rural poverty-gone forever is the euphoria of plenty. Asia's land has turned out to be unsuitable for the new strains-literally millions of people are still going to bed hungry. They are simply unable to find an occupation which will bring enough income. ...'

\section{The country}

India has a population of $591,699,000$ spread over an area of $3,287,782$ sq. $\mathrm{km}$. Majority of the people ( $80 \cdot 18$ per cent) live in 575,936 villages with poor communications.

There exist 4465 hospitals of all types, serving a population of 133,000 by unit. The better equipped hospitals with some specialisation departments are the 396 district hospitals. Teaching hospitals with all modern facilities are attached to the 106 medical colleges in the country. It is interesting to note only seven of them have a separate 'paraplegic unit', albeit looked after by a busy orthopaedic surgeon.

As per the health statistics of $1975-76$, population per bed is 1750 , population per doctor is 3940 and population per nurse is 6280, and the percentage of health expenditure to total Government Expenditure under plan is I.9 per cent with a per capita health expenditure of $9 \cdot 44$. 
The percentage of workers to total population (main activity only) stands at 32.93 per cent and most of them are engaged as cultivators and agricultural labourers $(69.67$ per cent).

India is relatively well developed industrially. It takes the tenth position in the industrial world. So as far as technological know-how is concerned India is a 'developed' country. But the simplicity of Indian life, its religious beliefs, its traditional clothing, ways of bathing and use of toilet, food and utensils, the inaccessibility of rural area and its economic problems claim for India a place amongst the developing countries. Thanks to planners the country has gone through five successive 5-year plan periods, since independence. It is important to know the targets set for the present Sixth plan period to understand why the problem of rehabilitation of the spinal cord injured is different.

'An essential part of the draft sixth plan (1978-83) is the minimum needs programme. Its objective is substantially and manifestly to improve conditions in a number of crucial areas, the beneficiaries being the poorest sections of the urban and rural population. school;

Specifically, the attempt will be to put some 32 million additional children in

- to make some 66 million out of Ioo million adult illiterates in the 15-35 age group literate;

- to provide a community health worker and trained 'dai' (traditional village midwife) for every thousand villagers;

- to give every block at least one Primary Health Centre;

- to open 38000 new sub centres and to upgrade about 400 PHCs into 30 -bed hospitals;

- to supply I00 000 villages with safe drinking water;

- to link all villages with not less than 1500 inhabitants and half of those with IO00 to I 500 people by roads; and

-to illuminate about 40000 villages.

'Furthermore, about 8 million landless labourers will be given developed house-sites, a drinking water source for every 30 houses, sanitation and some building materials. In the cities, living conditions for some 13 million slum dwellers will be improved. The nutrition scheme will be extended to benefit 2.6 million more children while an extra 4 million will be given midday meals.'

Today 250 million or more people live below the poverty line, the poverty line being defined by the Planning Commission as a minimum monthly income of of Rs. 62/- (7 U.S. dollars) for rural and Rs. 72 (8 U.S. dollars) for urban areas (at 1976-77 prices) and the daily consumption of at least 2400 calories in rural and 2100 calories in urban areas (based on 1973-74 consumer expenditure data). Nor is everyone above the poverty line more than marginally above it. That such large numbers of people have to exist in such penury is a fact.

\section{The problem}

No one disputes that an ounce of 'prevention', especially in spinal cord injured, is preferable to a 'pound' of cure. No one needs to be convinced how when a good spinal cord care system is well organised the mortality rate of 'paraplegics' has dropped to below 5 per cent and of the 'quadraplegics' to below 20 per cent. 
To achieve such encouraging figures a good set-up is essential. The ideal set-up will take a couple of decades, perhaps. But the present-day problem is how best to treat the type of neglected patient seen in our teaching hospitals. The reasons are umpteen unavoidable ones peculiar to our country.

\section{Statistics}

Based on incidence rates recently reported in the United States, it is estimated there could be approximately 33,480 new spinal cord injuries every year in India (J. F. KRUs, et al., Survival among persons sustaining Acute spinal cord injury, 1976).

All para- and quadraplegics treated at the four teaching hospitals and at other semi-teaching hospitals in Bombay city with a population of 7 million, eventually are rehabilitated at this Institute. Every year 25 such cases are, on the average, treated at the Institute, forming about I per cent of the 2530 new cases with orthopaedic disabilities.

The Nagpur association for the rehabilitation of children and adults with orthopaedic and other disabilities (NARCAOOD) did a survey of the paraplegic patients in the Nagpur area (first VRA-NARCAOOD project) covering an area of 9928 sq. $\mathrm{km}$ with $\mathrm{I}, 942,688$ population. The report published brought out interesting facts, shown in the following tables.

TABLE I

Paraplegic patients in two largest Nagpur Hospitals

\begin{tabular}{lrrc}
\hline & I966 & I967 & Total \\
\hline Hospital A & I05 & I I2 & 2I7 \\
Hospital B & 82 & 33 (incompleted) & I I5 \\
\hline
\end{tabular}

TABLE II

Analysis of 332 paraplegic cases

\begin{tabular}{|c|c|c|c|c|c|c|c|c|c|c|c|}
\hline \multirow{3}{*}{$\begin{array}{l}\text { Age } \\
\text { Sex }\end{array}$} & \multicolumn{8}{|c|}{ Aetiology, age and sex wise } & & & \multirow{3}{*}{$\begin{array}{c}\text { Grand } \\
\text { total }\end{array}$} \\
\hline & \multicolumn{2}{|c|}{$0-15$} & \multicolumn{2}{|c|}{ I6-30 } & \multicolumn{2}{|c|}{$3 I-45$} & \multicolumn{2}{|c|}{$46-65$} & \multicolumn{2}{|c|}{ Total } & \\
\hline & $M$ & $\mathrm{~F}$ & $M$ & $\mathrm{~F}$ & $M$ & $\mathrm{~F}$ & $M$ & $\mathrm{~F}$ & $M$ & $\mathrm{~F}$ & \\
\hline T.B. spine & I6 & 20 & 37 & 67 & 22 & I8 & I6 & 4 & 9I & 109 & 200 \\
\hline Fracture spine & 2 & I & 42 & 6 & I4 & 3 & I7 & 2 & 75 & 12 & 87 \\
\hline Syphilis & - & I & - & - & 4 & - & - & 一 & 4 & I & 5 \\
\hline Tumour & - & 一 & I & 2 & - & - & - & - & I & 2 & 3 \\
\hline Transverse myelitis & - & - & - & 2 & 5 & 3 & I & - & 6 & 5 & II \\
\hline Spondylolysthesis & - & - & - & I & 2 & - & 3 & I & 5 & 2 & 7 \\
\hline Others & 4 & 一 & 3 & 3 & 4 & I & 2 & 2 & I3 & 6 & I9 \\
\hline Total & 22 & 22 & 83 & $8 \mathrm{I}$ & $5 \mathrm{I}$ & 25 & 39 & 9 & 195 & I37 & 332 \\
\hline
\end{tabular}

This shows trauma was responsible for about 26 per cent and tuberculosis of the spine was the cause in 60 per cent of the cases. 
PAPERS READ AT THE ANNUAL SCIENTIFIC MEETING, I978

TABLE III

Income status of a sample of I 77 paraplegics

\begin{tabular}{lc}
\hline \multicolumn{1}{c}{ Rupees per month } & Number of cases \\
\hline (a) 25-50, i.e. 3 to 6 dollars & I I \\
(b) 5I-I00, i.e. 6 to I2 dollars & I39 \\
(c) IOI-200, i.e. I2 to 22 dollars & 24 \\
(d) 20I-300, i.e. 22 to 33 dollars & I \\
(e) Above 300, i.e. above 33 dollars & 2 \\
\hline
\end{tabular}

TABLE IV

Type of Trauma

\begin{tabular}{|c|c|c|c|}
\hline \multicolumn{2}{|l|}{ City } & \multicolumn{2}{|l|}{ Village } \\
\hline $\begin{array}{l}\text { Car accidents-no seat belts } \\
\text { Falling from-electric poles } \\
\quad \text { - seafolds } \\
\text { House collapsing } \\
\text { Industrial accidents }\end{array}$ & $\begin{array}{l}\text { Mostly pre- } \\
\text { ventable }\end{array}$ & $\begin{array}{l}\text { Falling } \\
\text {-into wells } \\
\text {-from trees } \\
\text {-roof top sleeping } \\
\text { - kite flying from } \\
\text { roofs }\end{array}$ & Preventable \\
\hline
\end{tabular}

Emergency care + acute care poor because : no trained personnel; no special wards.

Emergency care poor. Acute care poor because of late arrival to hospital.

\section{Model Plan}

Irrespective of the fact that traumatic paraplegia is not a priority area as far as health statistics are concerned, an ideal plan worked out successfully elsewhere, if applied, should involve:

Evacuation and Transport: requires cooperation of other depts; good communication network; trained evacuation personnel at all levels; medical supervision.

Transport: aerial transport; ambulances; jeeps and trucks; railways; bullock carts and man.

\section{Acute Care}

Emergency and acute care

-Possible in medical college hospitals.

-Dt. Hospitals not possible because of: late arrival; lack of beds; lack of expertise-Apathy!!

-Village: nil because of ignorance.

Under the circumstances already discussed the model plan is not likely to be practical. Appropriate solutions need to be sought at home. A national plan for spinal cord injured is neither possible at the moment nor is necessary. Existing facilities are to be utilised to yield best possible results. The inevitable are to be accepted and one must look for answers to problems that could be tackled. 
TABLE V

\begin{tabular}{|c|c|c|}
\hline \multicolumn{2}{|c|}{ Rehabilitation } & \multirow[t]{2}{*}{ Follow up } \\
\hline Physical & Vocational/educational & \\
\hline $\begin{array}{l}\text { Comprehensive medical } \\
\text { management } \\
\text { A.D.L. equipment } \\
\text { Psychological assessment } \\
\text { Social service }\end{array}$ & $\begin{array}{l}\text { Vocational evaluation: } \\
\text { counselling } \\
\text { training } \\
\text { work adjustment } \\
\text { placement }\end{array}$ & $\begin{array}{l}\text { I. Medical } \\
\text { 2. Vocational for adjustment } \\
\text { 3. Family } \\
\text { 4. Community }\end{array}$ \\
\hline $\begin{array}{l}\text { Family counselling to cope } \\
\text { Community placement }\end{array}$ & $\begin{array}{l}\text { Educational: } \\
\text { patient } \\
\text { community }\end{array}$ & How to reach Who to be trained \\
\hline
\end{tabular}

For preventive programme our best bets are the medical officers at the PHC and the patient and his family.

\section{P.H.C. doctors}

Basic knowledge as to the cause of morbidity and what simple precautions to be taken can be imparted to the doctor regarding: lifting patient, moving the patient, relieving pressure areas, joint movement, indwelling catheter, high fluid intake during transport and early removal to district hospital.

The medical personnel at the district and higher levels must be taught the importance of elementary preventive measures especially regarding bladder and skin, and gravity and importance of rehabilitation.

\section{Community}

The community health worker is poorly equipped to cope with the problem. But as the possible causes are so easily preventable at the village level, the health worker could educate the people as to the simple precautions to be taken.

Then at this level the patient and his family are the best persons to look into the emergency care and sending the injured to district hospital for acute care. They are motivated and realise the importance of it. In this manner one village is benefited, although at the cost of a paraplegic.

\section{Social integration}

Preparation for meaningful integration into the community by physical restoration should be our goal in a country with 80 per cent unemployment rate. At the most, self-employment through a skill may be attempted. The aim shall not be to get a job in the industrialised city thus dislocating the environment and exposing the person to new environmental hazards like isolation, and exposure to modern living and permissiveness causing eventual sexual frustration.

Independence in self care, mobility and health care maintenance under village conditions, will enable the patient to return to the community.

\section{Long-term follow-up}

Possible and desirable, and so should be encouraged to solve evolving problems: $(a)$ to enquire about educating the community regarding prevention, 
(b) health maintenance and prevention of further complications and (c) sex education.

\section{Evaluation}

Must be undertaken: $(a)$ to assess emergency or other treatment rendered at referral hospital or PHC, $(b)$ to improve knowledge, $(c)$ to evolve an effective plan based on what is possible and as to how to go about a regional centre, $(d)$ to find out remediable lacuna at all levels to reduce morbidity, (e) to make low-cost changes in architectural barriers, $(f)$ to evaluate improved methods of treatment and equipment needed and $(g)$ to modify aids and appliances to suit the environment.

\section{Conclusion}

A model plan for caring for the spinal cord injured cannot be universally applied. Much more so when traumatic Paraplegia is not a health priority area.

To be realistic the plan has got to be considered separately for the urban area where good facilities are available for transport and care, and for rural areas where such facilities are not possible in the near future. When hospital facilities are available only the Emergency and acute care programmes are taken care of at the moment. The importance of rehabilitation and follow up are neglected, though talked about. Emphasis must be laid on these two aspects and programmes so devised.

For the rural injured emergency care and acute care are remote possibilities, as things stand. Early rehabilitation at centres nearby should be aimed at. One has to rely on the rehabilitated patient and his family to educate the community on preventive measures and basic emergency care. One can't visualise a comprehensive plan to cover all the villages in the country. It is neither economically possible nor is it necessary. 